\section{Clinoptilolitic Zeolite as an Amendment for Establishment of Creeping Bentgrass on Sandy Media}

\author{
J.L. Nus ${ }^{1}$ \\ Department of Horticulture, Kansas State University, Manhattan, \\ KS 66506
}

\author{
S.E. Brauen ${ }^{2}$ \\ Washington State University, Puyallup Research and Extension Center, \\ Puyallup, WA 98371
}

Additional index words. turfgrass, soil amendments, sawdust, sphagnum peat, cation exchange capacity, water-holding capacity, exchangeable $\mathrm{K}^{+}$, exchangeable $\mathrm{NH}_{4}^{+}$

\begin{abstract}
In a field experiment, clinoptilolitic zeolite was compared to sphagnum peat and sawdust as sand amendments at $5 \%, 10 \%$, and 209 " (v/v) to enhance 'Penncross' creeping bentgrass (Agrostis palustris Huds.) establishment and to compare their gravimetric and volumetric cation exchange capacities and their effects on moisture retention and cation exchange capacities of the resultant mixes. In addition, cation exchange capacities and exchangeable $\mathrm{K}^{+}$and $\mathrm{NH}_{4}^{+}$were analyzed from clinoptilolitic zeolite of particle sizes ranging from $<0.25 \mathrm{~mm}$ to $>5.0 \mathrm{~mm}$. All amendments, except 10 ?ZO and 20\% sawdust, resulted in superior establishment compared to unamended sand. Peatamended sand retained significantly more moisture than sawdust- or zeolite-amended sand at - 6, - 10, - 33, and $-250 \mathrm{kPa}$ soil matric potentials. Zeolite exhibited a much higher volumetric cation exchange capacity than either sawdust or sphagnum peat. Cation exchange capacity and exchangeable potassium of clinoptilolitic zeolite was greatest when particle size was $<0.5 \mathrm{~mm}$; however, little exchangeable ammonium nitrogen was detected.
\end{abstract}

Quality turfgrass is most easily maintained on desirable root zones. Characteristics desired in a root zone include a high cation exchange capacity and adequate water retention (Beard, 1973). The characteristics of high-percentage sand mixes have been specified (Bengeyfield, 1970; Brown and Duble, 1975; Radko, 1974) and have gained popular acceptance because they resist compaction from excessive foot traffic. Because sands offer little capacity for nutrient and water retention, however, various organic amendments have been added. Peat is the most commonly used amendment (Beard, 1982), but sawdust, shredded bark, rice hulls, vermiculite, perlite, calcined clay, and sewage sludge have also been used (Kelley, 1989).

\footnotetext{
Received for publication 15 May 1990. Contribution no. 90-111-J of the Kansas State Agr. Expt. Sta. We thank Paul Haupt for technical assistance. Partial funding was provided by the Northwest Turfgrass Foundation. The cost of publishing this paper was defrayed in part by the payment of page charges. Under postal regulations, this paper therefore must be hereby marked advertisement solely to indicate this fact.

${ }^{1}$ Assistant Professor of Horticulture.

2Turfgrass Science Specialist.
}

Zeolites are crystalline, hydrated aluminosilicates. There are currently 40 types of zeolites known, as based on their chemical composition, structure, and related physical properties (Sand and Mumpton, 1978). Because of their specific three-dimensional structure, zeolites can act as molecular sieves (Breck, 1974). Clinoptilolitic zeolite (CZ) exhibits selective retention of $\mathrm{NH}_{4}^{+}$and $\mathrm{K}^{+}$ (Ferguson and Pepper, 1987; Hershey et al., 1980; Weber et al., 1983). Since N and K are the nutrients that are used in the highest amounts by turfgrass(Wray, 1974), the addition of $\mathrm{CZ}$ may selectively improve the nutrient status of sand root zones and provide better rates of establishment of bentgrass putting greens than nonamended root zones.

This experiment was designed to 1) compare $\mathrm{CZ}$ as an amendment to sawdust and

Table 1. Distribution (percent of total weight) of various particle sizes (mm) of sand and clinoptilolitic zeolite used in the amendment study.

\begin{tabular}{lccccccc}
\hline \hline & \multicolumn{7}{c}{ Particle size $(\mathrm{mm})$} \\
\cline { 2 - 8 } Material & $<0.25$ & $0.25-0.50$ & $0.50-1.0$ & $1.0-2.0$ & $2.0-4.7$ & $>4.7$ \\
\hline \multirow{2}{*}{ Sand } & 10.2 & 53.0 & Distribution (\%) & 32.3 & 3.7 & 0.8 & 0 \\
Zeolite & 7.5 & 1.8 & 3.8 & 12.8 & 19.4 & 54.7 \\
\hline
\end{tabular}
unamended sand and sand containing 5,\%0, sphagnum peat for the establishment of creeping bentgrass; 2) compare gravimetric and volumetric cation exchange capacities of the amendments; 3 ) determine the effects of all three amendments on moisture retention of the resultant mixes; and 4) quantify the cation exchange capacity, exchangeable $\mathrm{K}^{+}$, and $\mathrm{NH}_{4}^{+}$of $\mathrm{CZ}$ of various particle sizes.

A field experiment was conducted at Farm 5 of the Puyallup Research and Extension Center, Washington State Univ., Puyallup, to compare $\mathrm{CZ}$ with sawdust and sphagnum peat as amendments to sand (quartz) for the establishment of 'Penncross' creeping bentgrass from seed. Particle size of $\mathrm{CZ}$ was much more coarse than the sand (Table 1). Due to its high bulk density, however, CZ exhibits far superior volumetric cation exchange capacity (CEC) than either sawdust or sphagnum peat (Table 2). Treatments were arranged factorially in a completely randomized block design with three types of amendments, four amounts $[0 \%, 570,10 \%$, and $20 \%(\mathrm{v} / \mathrm{v})]$, and three replications. Each plot was $1 \times 2$ $\mathrm{m}$ and contained the mix to a depth of 30 $\mathrm{cm}$ over natural soil (Puyallup sandy loam) with no underlying coarse sand or gravel layer. Mixing was done off site with a large industrial mixer, and removable wooden frames were used to fill each plot with the appropriate mix. After the mixes were in place and compacted with a water ballast roller, the wooden frames were removed from each plot and border integrity remained intact. Plots were seeded with $48.8 \mathrm{~kg}$ of 'Penncross' creeping bentgrass/ha and supplied with 38.7 $\mathrm{kg} \mathrm{N}, 45.4 \mathrm{~kg} \mathrm{P}$, and $40.3 \mathrm{~kg} \mathrm{~K} / \mathrm{ha}$ from diamonium phosphate $\left(18 \mathrm{~N}-48 \mathrm{P}_{2} \mathrm{O}_{5}-0 \mathrm{~K}_{2} \mathrm{O}\right)$ and potassium chloride $\left(0 \mathrm{~N}-0 \mathrm{P}_{2} \mathrm{O}_{5}-60 \mathrm{~K}_{2} \mathrm{O}\right)$ immediately after seeding. Establishment ratings $(1-9 ; 1=$ no cover, $9=$ complete fill) were taken 3 and 4 weeks after seeding. Data were combined. from both weeks for statistical analyses. Establishment ratings were tested by analysis of variance procedures (Steel and Torrie, 1960), and means (six observations per mean) were separated by least significant difference $(P<0.05)$ methods between amendment types for each rate.

Moisture contents (dry-weight basis) of $10 \%$, and $20 \%(\mathrm{v} / \mathrm{v})$ sphagnum peat, sawdust, and $\mathrm{CZ}$ were determined at $-6,-10$, -33 , and $-250 \mathrm{kPa}$ soil matric potentials, 
as described by Topp and Zebchuk (1979), using a pressure-plate moisture extractor (Soil Moisture Equipment Corp., Santa Barbara, Calif.) after firming each mix to a bulk density of 1.3 to $1.45 \mathrm{~g} \cdot \mathrm{cm}^{-1}$. Five samples of each mix were evaluated, and analysis of variance procedures and least significant difference methods (Steel and Torrie, 1960) were used to separate mean moisture contents of each amendment type at $-10 \mathrm{kPa}$ matric

Table 2. Bulk density and gravimetric and volumetric cation exchange capacities (CEC) of sand, clinoptilolitic zeolite, sawdust, and sphagnum peat.

\begin{tabular}{|c|c|c|c|}
\hline \multirow[b]{2}{*}{ Material } & \multirow{2}{*}{$\begin{array}{l}\text { Bülk density } \\
\left(\mathrm{g} \cdot \mathrm{cm}^{-3}\right)\end{array}$} & \multicolumn{2}{|c|}{$\mathrm{CEC}$} \\
\hline & & $\mathrm{meq} / 100 \mathrm{~g}$ & meq/liter \\
\hline Sand & 1.68 & 2.6 & 43.7 \\
\hline Zeolite & 1.11 & 61.3 & 680 \\
\hline Sawdust ${ }^{\mathbf{z}}$ & 0.25 & $10-60$ & $25-150$ \\
\hline Peat $^{2}$ & 0.10 & $100-150$ & $100-150$ \\
\hline
\end{tabular}

${ }^{\mathrm{z}}$ Values for sawdust and peat from Hershey et al., 1980 .

Table 3. Effect of amendment type at various volumes on average establishment ratings of creeping bentgrass (data pooled for 3 and 4 weeks after seeding).

\begin{tabular}{|c|c|c|c|c|}
\hline \multirow[b]{2}{*}{ Amendment } & \multicolumn{4}{|c|}{ Amendment volume (\%) } \\
\hline & 0 & 5 & 10 & 20 \\
\hline & \multicolumn{4}{|c|}{ Average establishment rating } \\
\hline Sawdust & 5.2 & 6.8 & 5.7 & 5.8 \\
\hline Peat & 5.2 & 6.8 & 7.3 & 7.9 \\
\hline Zeolite & 5.2 & 7.0 & 7.5 & 8.2 \\
\hline $\operatorname{LSD}^{y}$ & -- & NS & 1.1 & 1.6 \\
\hline
\end{tabular}

${ }^{\mathrm{z}}$ Rating: 1 = no coverage, 9 = complete coverage. Each value represents the average of six observations.

${ }^{\mathrm{y}}$ Mean separation within columns by least significant difference method, $P=0.05$.

Table 4. Effect of amendment type at various volumes on moisture content at $-10 \mathrm{kPa}$ matric potential.

\begin{tabular}{lcccc}
\hline \hline & \multicolumn{5}{c}{ Amendment volume (\%) } \\
\cline { 2 - 5 } Amendment & 0 & 5 & 10 & 20 \\
\hline \multicolumn{5}{c}{ Moisture content $(\%)$} \\
Sawdust & 2.63 & 3.24 & 4.29 & 5.88 \\
Peat & 2.63 & 4.03 & 5.68 & 8.83 \\
Zeolite & 2.63 & 3.15 & 3.88 & 5.11 \\
LSD $^{y}$ &.-- & 0.28 & 0.50 & 0.66 \\
\hline
\end{tabular}

${ }^{\mathrm{z}}$ Dry-weight basis.

${ }^{\mathrm{y}}$ Mean separation within columns by least significant difference method, $P=0.05$. Each value represents mean of five observations. potentials within each amendment volume and

at $10 \%$ volume within matric potentials.

CEC and exchangeable $\mathrm{NH}_{4}^{+}$were determined, as described by Black (1965), and exchangeable $\mathrm{K}$ was determined, as described by Dahnke (1988), for three replicates from each of nine groups of $\mathrm{CZ}$ ranging in particle size from $<0.25 \mathrm{~mm}$ to $>5.0 \mathrm{~mm}$. Analysis of variance and least significant difference procedures (Steel and Torrie, 1960) were performed to separate $\mathrm{CEC}$, exchangeable $\mathrm{K}^{+}$, and $\mathrm{NH}_{4}^{+}$means between particle size groups.

The addition of amendments enhanced bentgrass establishment, except for sawdust at $10 \%$ and $20 \%(\mathrm{v} / \mathrm{v})$ (Table 3 ). Establishment for unamended sand $(0 \%$ amendment volume) was quite poor, reflecting the difficulty in establishing bentgrass greens on $100 \%$ sand. At $5 \%$ amendment volume; no statistical differences were observed between sawdust, peat, and CZ mixes (Table 3), but at the $10 \%$ and $20 \%$ levels, both sphagnum peat and $\mathrm{CZ}$ were equally more effective as amendments than sawdust for establishing creeping bentgrass.

The poor performance of sawdust (mostly Douglas fir) as a sand amendment at the higher levels may be attributed to the depletion of available $\mathrm{N}$ by decompose organisms. Although the decomposition of Douglas fir sawdust is slow compared to other softwood species (Allison and Klein, 1961), the relatively high $\mathrm{C}: \mathrm{N}$ ratio and high cellulose content of sawdust (Anderson, 1957) provides a base for stimulated microbial activity that is in direct competition with the seedling turf for available N (Walker, 1975). Plots receiving $10 \%$ and $20 \%$ sawdust exhibited thinner stands and appeared lighter green, indicative of $\mathrm{N}$ deficiencies, although no tissue samples were analyzed. Such establishment inhibition by sawdust at the $10 \%$ and $20 \%$ levels might not have occurred, however, if the sawdust had been allowed to weather for 2 to 7 months before use (Waddington et al., 1967).

Amendments are added to sand to improve both nutrient and moisture retention (Beard, 1973). At all levels at which the amendment was included, the addition of sphagnum peat resulted in higher moisture retention of the sand mix than the addition of either sawdust or CZ (Tables 4 and 5). Moisture contents of sawdust- and CZ-amended sand differed significantly from each other only at the $20 \%$ volume, although all amendments enhanced moisture content of unamended sand (Tables

Table 5. Moisture contents $\mathrm{z}^{\mathrm{z}}$ of sand and sand mixes containing $10 \%(\mathrm{v} / \mathrm{v})$ of sphagnum peat, sawdust, and clinoptilolitic zeolite at $-6,-10,-33$, and $-250 \mathrm{kPa}$ soil matric potentials.

\begin{tabular}{lcccc}
\hline \hline & \multicolumn{4}{c}{ Soil matric potential (kPa) } \\
\cline { 2 - 4 } Mix & -6 & -10 & -33 & -250 \\
\hline & & \multicolumn{4}{c}{ Moisture content (\%) } \\
Sand only & 3.51 & 2.63 & 1.74 & 1.19 \\
Sand + peat & 7.31 & 5.68 & 3.70 & 3.34 \\
Sand + sawdust & 5.85 & 4.29 & 2.80 & 2.46 \\
Sand + zeolite & 5.17 & 3.88 & 2.72 & 2.60 \\
LSD & 0.84 & 0.50 & 0.48 & 0.27 \\
\hline
\end{tabular}

${ }^{\mathrm{z}}$ Values represent means of five samples compacted to bulk densities of 1.3 to $1.45 \mathrm{~g} \cdot \mathrm{cm}^{-3}$ and are expressed on a dry-weight basis.

${ }^{\mathrm{y}}$ Mean separation within columns by least significant difference method, $P=0.05$.
4 and 5). Under conditions where irrigation may be limited, sphagnum peat would provide superior moisture status to the creeping bentgrass root zone, relative to either sawdust or zeolite.

For the $10 \%$ volume mixes, moisture retention consistently was best in peat-amended sand as the mixes dried (Table 5). Moisture retention of sawdust- and $\mathrm{CZ}$-amended sand did not differ significantly, but the addition of either amendment significantly improved water retention at all soil matric potentials compared to sand only. Knowlton and White (1981) have reported that CZ has a higher water-holding capacity than sand, and Ferguson et al. (1986) attributed enhanced germination and quality of creeping bentgrass to enhanced moisture retention of zeoliteamended sand mixes.

Although adequate levels of $\mathrm{P}$ are emphasized in seedling establishment (Beard, 1973), since both $\mathrm{N}$ and $\mathrm{K}$ are used in high amounts by turfgrasses (Wray, 1974), selective retention of these nutrients in zeolite-amended sand root zones may, at least partially, account for the enhanced establishment of CZamended sand mixes. Ferguson et al. (1986) attributed superior $\mathrm{N}$ use efficiency and quality of creeping bentgrass growing in CZ-amended sand to the ability of $\mathrm{CZ}$ to absorb and protect $\mathrm{NH}_{4}^{+}$from vitrifying bacteria. MacKown and Tucker (1985) reported that zeolite effectively enhanced retention of $\mathrm{NH}_{4}^{+}$and reduced the amount of $\mathrm{N}$ leached from coarsetextured soils.

Maximum cation exchange capacity and exchangeable $\mathrm{K}^{+}$was observed when particle size was $<0.5 \mathrm{~mm}$; however, very little exchangeable $\mathrm{NH}_{4}^{+}$was present in any of the CZ samples (Table 6). The CZ used in this study was very coarse compared to the sand (Table 1). It follows that maximum CEC and exchangeable $\mathrm{K}^{+}$enhancement of the sand could have been realized using smaller particles, such as those used by Hershey et al. (1980) and Ferguson et al. (1986).

The U.S. Golf Association specifies that properly constructed sand greens possess a root zone bulk density of 1.2 to $1.6 \mathrm{~g} \cdot \mathrm{cm}^{-3}$ (Beard, 1982). Because the bulk density of sphagnum peat is only $0.1 \mathrm{~g} \cdot \mathrm{cm}^{-3}$ (Table 2), the upper limit on the amount of peat that can be used as a sand amendment is $\approx 15 \%$ to $20 \%(\mathrm{v} / \mathrm{v})$. Although bulk density of sand and zeolite depend on particle size, particle density of $\mathrm{CZ}$ is $2.1 \mathrm{~g} \cdot \mathrm{cm}^{-3}$ (Ferguson et al., 1986), similar to that of sand $\left(2.7 \mathrm{~g} \cdot \mathrm{cm}^{-3}\right)$; therefore, such upper limits of peat-amended mixes may not be applicable to CZ-amended sand. Even at levels used in this study, however, the potential for improving the cation exchange capacity of sand mixes is very high using CZ because of its extremely high volumetric CEC compared to either sawdust or peat (Table 2). As Ferguson et al. (1986) reported, $\mathrm{CZ}$ possesses the desirable physical properties associated with sand and the favorable chemical characteristics associated with clay.

Although establishment of seeded creeping bentgrass was enhanced with $\mathrm{CZ}$ volumes up to $20 \%$ in this study, Ferguson et 
Table 6. Influence of particle size on cation exchange capacity (CEC), exchangeable K, and exchangeable ammonium nitrogen of clinoptilolitic zeolite.

\begin{tabular}{|c|c|c|c|}
\hline \multirow[b]{2}{*}{$\begin{array}{l}\text { Particle size } \\
(\mathrm{mm})\end{array}$} & \multirow[b]{2}{*}{$\begin{array}{c}C E C \\
\text { (meq } / 100 \text { grams) }\end{array}$} & \multicolumn{2}{|c|}{ Exchangeable } \\
\hline & & $\begin{array}{c}\mathrm{K}^{+} \\
\left(\mathrm{mg} \cdot \text { liter-1) }^{-1}\right) \\
\end{array}$ & $\begin{array}{c}\mathrm{NH}_{4}^{+} \\
\text {(mg } \cdot \text { liter }-1)\end{array}$ \\
\hline$<0.25$ & $169.0^{z}$ & 11700 & 3.5 \\
\hline $0.25-0.32$ & 165.8 & 10900 & 5.7 \\
\hline $0.32-0.42$ & 169.0 & 9970 & 3.4 \\
\hline $0.42-0.64$ & 157.4 & 8210 & 3.4 \\
\hline $0.64-1.0$ & 132.5 & 5620 & 7.0 \\
\hline $1.0-2.0$ & 62.6 & 3680 & 3.4 \\
\hline $2.0-3.0$ & 47.8 & 4770 & 1.5 \\
\hline $3.0-5.0$ & 40.0 & 7310 & 4.5 \\
\hline$>5.0$ & 45.6 & 7830 & 1.5 \\
\hline $\mathrm{LSD}^{\mathrm{y}}$ & 10.1 & 643 & NS \\
\hline
\end{tabular}

${ }^{2}$ Values represent means of three samples.

"Mean separation within columns by least significant difference method, $\boldsymbol{P}=\mathbf{0 . 0 5}$.

al. (1986) showed better bentgrass establishment on $5 \% \mathrm{CZ}$ than on $10 \% \mathrm{CZ}$ volume plots. They attributed this higher rate inhibition to high sodium content. The lack of establishment inhibition with $10 \%$ and $20 \%$ $\mathrm{CZ}$ in this study may be due to the very coarse $\mathrm{CZ}$ we used. Most of the zeolite used was gravel size (Table 1), whereas the $\mathrm{CZ}$ used by Hershey et al. (1980) and Ferguson et al. (1986) was the size of medium-coarse and very coarse sand, respectively. Although Ferguson et al. (1986) reported that most of the sodium was leached within 5 to 6 months, finer-grade $\mathrm{CZ}$ ( $<1 \mathrm{~mm}$ particle size) may need to be leached of high levels of sodium before volumes $\geq 10 \%$ enhance seedling establishment.

This study has shown that coarse-grade $\mathrm{CZ}$ compares favorably with sphagnum peat and sawdust as amendments for the establishment of creeping bentgrass putting greens and suggests enhanced establishment is due to both increased moisture and nutrient status. However, before general recommendations concerning the use of clinoptilolitic zeolite as an alternative sand amendment can be made, long-term studies need to be done to evaluate its resistance to breakdown and to establish leaching requirements to reduce any possible detrimental effects of the relatively high sodium content of the material.

\section{Literature Cited}

Allison, F.E. and C.J. Klein. 1961. Comparative rates of decomposition in soil of wood and bark particles of several softwood species. Soil Sci. Soc. Amer. Proc. 25:193-196.

Anderson, M.S. 1957. Sawdust and other natural organics for turf establishment and soil improvement. U.S. Dept. Agr., Agr. Res. Serv. Circ. 41-18. Prentice-Hall, Englewood Cliffs, N.J.

Beard, J.B. 1982. Turf management for golf courses. Burgess, Minneapolis.

Bengeyfield, W.H. 1970. Turfgrass soils and their modification. USGA green mixes. Proc. 1st Intl. Turfgrass Res. Conf., Sports Turf Res. Inst., Bingley, U.K. p. 149-150.

Black, C.A. (ed.). 1965. Methods of soil analysis. Part 2. Amer. Soc. Agron., Madison, Wis.

Breck, D.W. 1974. Zeolite molecular sieves. Wiley, New York.

Brown, K.W. and R.L. Duble. 1975. Physical characteristics of soil mixtures used for golf green construction. Agron. J. 67(5):647-652.

Dahnke, W.C. (ed.). 1988. Recommended chemical soil test procedures for the north central
Beard, J.B. 1973. Turfgrass: Science and culture. region. North Dakota State Univ. Bul. 499.

Ferguson, G.A. and I.L. Pepper. 1987. Ammonium retention in sand amended with clinoptilelite. Soil Sci. 51(1):231-234.

Ferguson, G.A., I.L. Pepper, and W.R. Kneebone. 1986. Growth of creeping bentgrass on a new medium for turfgrass growth: Clinoptilolite zeolite-amended sand. Agron. J. 78(6):10951098.

Hershey, D.R., J.L. Paul, and R.M. Carlson. 1980. Evaluation of potassium-enriched clinoptilolite as a potassium source of potting media. HortScience 15(1):87-89.

Kelley, M. 1989. Facts on organic soil amendments. Grounds Maintenance 24(2):74-108.

Knowlton, G. and T. White. 1981. Thermal study of types of water associated with clinoptilolite. Clays Clay Miner. 29:403-411.

MacKown, C.T. and T.C. Tucker. 1985. Ammonium nitrogen movement in a coarse-textured soil amended with zeolite. Soil Sci. Soc. Amer. J. 49:235-238.

Radko, A.M. 1974. Refining green section specifications for putting green construction, p. 287297. In: E.C. Roberts (ed.). Proc. 2nd Intl. Turfgrass Res. Conf., Blacksburg, Va. Amer. Soc. Agron., Madison, Wis.

Sand, L.B. and F.A. Mumptom (eds.). 1978. Natural zeolites: Occurrence, properties, use. Permagon Press, New York.

Steel, R.G. and J.H. Torrie. 1960. Principles and procedures of statistics. McGraw-Hill, New York.

Topp, G.C. and W. Zebchuk. 1979. The determination of soil-water desorption curves for soil cores. Can. J. Soil Sci. 59:19-26.

Waddington, D.V., W.C. Lincoln, Jr., and J. Troll. 1967. Effect of sawdust on the germination and seedling growth of several turfgrasses. Agron. J. 59(1):137-139.

Walker; N. 1975. Soil microbiology. Wiley, New York.

Weber, M.A., K.A. Barbarick, and D.G. Westfall. 1983. Ammonium adsorption by a zeolite in a static and a dynamic system. J. Env. Qual. 12(4):549-552.

Wray, F.J. 1974. Seasonal growth and major nutrient uptake of turfgrasses under cool, wet conditions, p. 79-88. In: E.C. Roberts (ed.). Proc. 2nd Intl. Turfgrass Res. Conf., Blacksburg, Va. Amer. Soc. Agron., Madison, Wis. 